Article

\title{
Free Speech Under Pressure: The Effect of Online Harassment on Literary Writers
}

\author{
Juliane Wegner $^{1}$, Elizabeth Prommer ${ }^{1, *}$ and Carlos Collado Seidel ${ }^{2}$ \\ ${ }^{1}$ Institute for Media Research, University of Rostock, 18055 Rostock, Germany; \\ E-Mails: juliane.wegner@uni-rostock.de (J.W.), elizabeth.prommer@uni-rostock.de (E.P.) \\ 2 Department of History and Cultural Studies, Philipps-University Marburg, 35032 Marburg, Germany; \\ E-Mail: carlos.colladoseidel@staff.uni-marburg.de \\ * Corresponding author
}

Submitted: 12 May 2020 | Accepted: 18 August 2020 | Published: 15 October 2020

\begin{abstract}
In the perception of writers in Germany, free speech is under strong pressure. A survey study, in which 526 literature writers took part, reveals innumerable aspects of hate speech, online harassment, and even physical assaults. Every second person has already experienced assaults on his or her person and is also aware of attacks on colleagues. Three quarters are concerned about freedom of expression in Germany and complain of an increase in threats, intimidation, and hateful reactions. The research project was developed in collaboration between the Institute for Media Research, University of Rostock, and the PEN Center Germany.
\end{abstract}

\section{Keywords}

democratic discourse; freedom of expression; hate speech; self-censorship

Issue

This article is part of the issue "Freedom of Expression, Democratic Discourse and the Social Media" edited by Maria Elliot (Linnaeus University, Sweden) and Kristoffer Holt (Linnaeus University, Sweden).

(C) 2020 by the authors; licensee Cogitatio (Lisbon, Portugal). This article is licensed under a Creative Commons Attribution 4.0 International License (CC BY).

\section{Introduction}

Not only is free speech an essential requirement for democratic states, it is also a key factor for a diverse and inclusive society. The diversity of ideas and opinions together with public discourse and critical reflection form the basis of democratic societies. This requires the freedom of speech as a central aspect that is anchored in the German constitution (German Basic Law) and constitutions of many other countries as well. This ideal is also grounded through the inclusive function (Beck, 2015 , p. 103) of the media. The ideal calls for an open system that represents a plurality of opinions through the media, with the ability to transmit and grant visibility to the entire spectrum and diversity of ideas. Here, the public spheres of the digital realm provide opportunities and ample potential to heighten the visibility of pre- viously so-called marginalized groups and perspectives (Habermas, 1990). But at the same time we are currently experiencing social movements, in particular in the digital public sphere-Altmeppen et al. (2019, p. 70) call these "competing public arenas" - that seeks to use the discursive space not just to present a contrasting viewpoint, but to spread hate. Digital public spheres play a key role in the emergence of so-called hate speech and shitstorms (cf. Duggan et al., 2014; Leets, 2002; Nolden, 2020; Rieger, Schmitt, \& Frischlich, 2018; Springer, 2014).

There is the notion that the spreading of online hate in recent times has become a threat to free speech and open discourses. It has become subject to academic research but also to political interventions. 'Hate on the web' is now met in Germany with new regulations. Several cases concerning politicians receiving hate and defamatory statements have led to the court decisions 
and lately to new laws relating to hate speech (Höhne \& Reimann, 2019).

The premise for this study is the observation that functional social integration requires both diverse mass media and an open digital social media to provide a space where the different opinions found in society can manifest themselves. This raises the question in what way free speech comes under attack by verbal counter movements manifested in hate comments, shitstorms, and online harassment, since people might refrain from voicing their opinion in fear of such attacks in a poisoned environment. Sponholz remarks: "Hate speech poses a threat through its deteriorating effect on coexistence in modern societies and thus our collective future" (Sponholz, 2018, p. 443).

Unlike many studies (Obermaier, Hofbauer, \& Reinemann, 2018; Papendick, Rees, Wäschle, \& Zick, 2020), which focus on journalists, we are focusing on literature writers, such as essayists, novelists, or poets, not journalists. Writers of novels, biographies, essays, fiction, or science books are also active participants in the public-digital sphere, as they shape it in complex ways. Literature is dependent on the public sphere and vice versa. The digital media environment and the new modes of communication established by it affect the field of literature. The digital space offers writers a great variety of opportunities "for the production of texts, for the communication with the readers, for the inclusion of people who did not have access to culture before, for the inspiration to new ideas, perhaps even for the exchange...among readers" (Zeh, 2012, p. 3). Literary work thus plays an integral part in the processes of inclusion. This is particularly true for the digital public sphere.

Writers have been subject to online hate and controversial discussion. In Germany, a prominent example is the debate around Peter Handke, winner of the 2019 Nobel Prize for Literature. Austrian author Peter Handke has received his Nobel Prize for Literature in 2019 and the Swedish Academy faced intense criticism for the choice. Peter Handke is accused of supporting the genocidal Serbian regime led by Slobodan Milošević and of denying the extent of Serbian terror and killing during the 1990s in former Yugoslavia. Since the announcement of the prize, international writers and human rights campaigners have called upon the members of the Swedish Academy to change their minds, via online campaigns, twitter storms, and press (cf. Thorpe, 2019). This is an example of the ambivalence encountered in the digital public sphere. It is in this sense that Struth describes the deliberation between freedom of speech and the potential toleration of anti-democratic statements as a "democratic dilemma" (Struth, 2019, p. 37).

Literary authors and writers, unlike journalists, are usually not subject to direct physical attacks, as they happen for instance at demonstrations. However, writers working in Germany have reported encounters with hate speech, harassment, and even physical assaults at lectures, a development which has brought the German writers' union and the German PEN Center to raise the question of how widespread such attacks actually are, in how far they endanger freedom of expression and what their consequences for the work of the writers are. Based on this question, the Institute for Media Research at the University of Rostock and the German PEN Center conducted an online survey study (2018). The initial goal was to evaluate the type and frequency of attacks on writers with a focus on digital public spheres, as well as the evaluation of potential effects on the persons affected. Do offline or online attacks lead to a form of selfcensorship and thus endanger the visibility of perspectives and opinions? The German PEN Center has established itself as an advocate of free speech and is regarded as a strong voice of persecuted and oppressed writers (cf. German PEN Center, n.d.).

The German PEN Center is the national affiliation of PEN International, an international institution to promote freedom of expression since the early 1920s. PEN is an acronym of Poets, Essayists, Novelists. Their principles are:

PEN stands for the principle of unhampered transmission of thought within each nation and between all nations, and members pledge themselves to oppose any form of suppression of freedom of expression in the country and community to which they belong, as well as throughout the world wherever this is possible. PEN declares for a free press and opposes arbitrary censorship in time of peace. (PEN International, n.d.)

In Germany, the PEN Center has about 800 members. To become a member, one needs to be introduced by two PEN members and all members decide upon membership. Membership goes to literary authors (Poets, Essayists, Novelists) who have reached "special literary achievements;" this usually includes having their books published with well-known and respected publishing companies. Journalists, bloggers, and academics are usually not members. On the other hand, this does not exclude that PEN members will write essays or commentaries that are published in newspapers.

This study sheds a light on literary writers as a rarely investigated group in this context. It pursues the question whether professional self-limitation-or selfcensorship in the most extreme case-are currently evident in Germany and which forms they take.

\section{Literature Review}

Research has centred mainly on journalists, intersectional relations, the form of the assaults, and the effect online attacks have, but rarely have dealt with literary authors. Recent international comparative studies have shown that attacks on journalists are on the rise. A high number of "physical assaults, threats and intimidations" (Reporters Without Borders Germany, 2018, p. 1) have been reported. It is debated if this leads the way to 
self-censorship once writers start reconsidering whether they should research and work on a certain issue that could provoke harassment (Binns, 2017; Löfgren Nilsson, \& Örnebring, 2016).

Preuß, Tetzlaff, and Zick (2017) and the European Center for Press and Media Freedom have studied experiences of harassment. The key results show that almost half $(42 \%)$ of the 780 responding journalists had experienced harassment in 2016 and that media outlets, such as newspapers or television, are increasingly affected (Preuß et al., 2017, p. 3). An extra level of danger exists during visits to events organised by or related to the spectrum of the political far-right (Betche \& Hoffmann, 2018, p. 11). In summary, one important origin of the hate-speech are right-wing-political groups in Germany (Sorce, 2020). Journalists reporting about right-wing demonstrations have repeatedly been victims of violence or assaults. Even the free media have been denounced as "Lying Press" by representatives of the right-wing party Alternative for Germany (Freedom House, 2017, p. 22). For the definitions of the different right-wing groups in Germany, please see the glossary in the Supplementary File.

Another comparative approach on the international level is used in the study Journalists under Pressure (Clark \& Grech, 2017) that focuses on the subject of self-censorship. Key takeaways are that half (53\%) of the 940 responding journalists from countries across Europe have experienced harassment online (cf. Clark \& Grech, 2017, p. 11). In the context of the study, self-censorship is defined very broadly as the consideration whether a journalist is likely to encounter negative effects by looking at a particular issue and in consequence chooses to drop the subject. For $63 \%$ of the respondents this was the case: They practised "self-censorship-the control of what one says or does in order to avoid annoying or offending others but without being told officially that such control is necessary" (Clark \& Grech, 2017, p. 11).

Research by Obermaier et al. (2018) shows that the clear majority of journalists in Germany (over 70\%) are rarely attacked personally but observe attacks on colleagues. Nevertheless, a majority of journalists sees this as a growing problem and assumes that hate speech negatively affects the sentiment towards journalists in society.

Several studies find correlation between gender (Binns, 2017), sexual orientation (Sweeney, 2015), race (Nolden, 2020), and the amount of hate-speech received. An analysis by the newspaper The Guardian showed that the 10 people receiving the most negative comments in the online commentary section were eight women and two black men (Gardiner et al., 2016). Eckert (2017) interviewed women who blog about politics or identify themselves as feminists in Germany, Switzerland, the United Kingdom, and the United States. They face great risks of online abuse. In-depth interviews revealed that $73.4 \%$ had negative experiences due to blogging and/or social media use. Most of these negative experiences involved not only abusive comments but also stalking, trolls, rape threats, death threats, and unpleasant offline encounters.

Stahel and Schoen (2019) found out that female journalists are more likely to use avoidance strategies as a reaction to online attacks than male journalists, since the attacks affect and stress them more. Avoidance includes limiting audience engagement, adapting reporting behaviour, and thinking about quitting journalism (Chen et al., 2018).

A study by PEN America found comparable results. According to this study two-thirds of the responding literature writers reported having avoided a controversial issue in the past (PEN America, 2015). A similar study (PEN America, 2017), geared at journalists and writers with experience of harassment, shows the impact such attacks have on the writers and journalists. 67 percent of survey respondents reported having a severe reaction to their online harassment, including: fearing for their safety or the safety of their beloved ones; refraining from publishing their work; and/or permanently deleting their social media accounts. Changing social media behaviour or even taking a break is also one of the reactions.

Besides all benefits, online media also offer a space in which online hate (i.e., cyberhate, hate speech, and extremism) flourishes. The content of online harassment has been studied extensively, often in the context of mobbing and more recently with a focus on hate speech. Forms of online harassment in the German-speaking area are often aligned in research in three central negative internet phenomena (Amadeu-Antonio-Stiftung, 2016; Prinzing, 2015): flaming (pure insult), hate speech (discrimination), and shitstorms. According to Meibauer, hate speech in general is "the verbal expression of hatred against persons or groups of people" (Meibauer, 2013 , p. 1). Key influence factors for negative communication online are anonymity and the lack of identifiability of the authors. Opinions are presented or formulated in a drastic manner, which would never be employed in face-to-face communication. At the same time, the risk of encountering aggressive and insulting behaviour increases (cf. Mayer-Uellner, 2003, p. 207; Reid-Steere, 2000 , p. 275). Schütte speaks of "performance" in this context, meaning the display of provocative behaviour that aims to generate denunciation or support and to "revel in user reactions" (Schütte, 2013, p. 135). Schmitt puts emphasis on incentives such as distinction, intimidation, dominance, and sovereignty of interpretation, as well as fun and excitement (Schmitt, 2017, pp. 52-55).

Rieger et al. (2018) conceptualize online hate as:

Norm transgressing communication that is (1) characterized by the derogation and defamation of single individuals (offensive speech) as well as members of targeted social groups (hate speech), (2) spread by individual users, social bots, as well as social groups or state actors...(3) motivated by personal, social, as well as ideological factors. (Rieger et al., 2018, p. 461) 
The consequences of hate speech in the digital public sphere are manifold. On the audience side, Eckes, Fernholz, Geschke, Klaßen, and Quent (2019) found that one out of two internet users report that in reaction to hate speech they are less inclined to reveal their personal political point of view on the internet (54\%), as well as less inclined to participate in debates online (47\%). This means "that people are systematically pushed out of online discussions through hate messages.... Not only the affected persons suffer from this, but also online pluralism in general and in consequence the democratic culture of discourse as well" (Geschke, Klaßen, Quent, \& Richter, 2019, p. 2).

Obermaier et al. (2018, p. 502) sum up:

Hate speech, especially online hate, directed at journalists might be problematic because it carries the potential of negative effects on journalists themselves and, in turn, on journalistic work (cf. Leets, 2002; Seethaler et al., 2019, p. 246). First, hate speech might impede the ability of journalists to fulfil their duties as it potentially puts them under stark emotional pressure, induces stress and fear, for instance, when they themselves or their families are threatened. Also, this could lead to a reduction in well-being or job satisfaction. Second, hate speech could intimidate journalists to such an extent that they would frame certain topics differently or avoid reporting on certain conflict-prone topics at all. (Obermaier et al., 2018, pp. 502-503)

Hate-speech has manifold effects but is produced only by a small percent of the audience. Springer (2014) studies various newspapers' online comment-sections in her work and highlights that the majority of media users (95\%) tend to act passively and neither comment on nor 'like' online texts. Comments are in fact only generated by a small number of people (cf. Springer, 2014). This result is supported by Krone's study of an Austrian daily newspaper (Krone, 2019). A study by Weber, Prochazka, and Schweiger (2015, p. 26) reveals that "rude" user comments have a negative effect on the perception of the quality of a given text and make media outlets appear untrustworthy.

Summarising the state of research, it shows that empirical studies with a particular focus on writers in Germany are scarce. This study should fill this gap. The focus is on the form and scope of negative experiences, as well as on the consequences they have for the literary work.

\section{Method and Respondents}

In line with the literature review, our guiding questions are: Do literary writers have personal experience with hate speech, online harassment, shitstorms, or other forms of assault? Which issues are likely to stimulate harassment? How does this show up in their work? Does this lead to self-censorship? To answer these questions, we conducted a standardised online survey among authors and writers with open and closed questions addressing these topics. The online questionnaire was developed together with the German PEN Centre adjusting questions of journalistic surveys (such as Preuß et al., 2017, or Reporters Without Borders Germany, 2018) to literary authors and adding themes.

The link to the online questionnaire was distributed by email among all German PEN members, about 800 people in June 2018 . We also tried to distribute the questionnaire via the writer's unions (e.g., regional associations of the German writers' union) a week later. Nevertheless, the return rate and dates show that the respondents mainly consist of the PEN membership. The design of the survey prevented repeated participation by logging IP addresses. The return shows that 526 persons answered the questionnaire.

On the basis of the online survey of these 526 responding writers, we can assess the writers' personal views regarding freedom of expression and their individual experiences of online harassment and shitstorms. Furthermore, the survey inquired about changes of behaviour and self-limitation.

Of the questioned writers, the participation of women and men is balanced, with $51 \%$ identifying themselves as women and $48.4 \%$ as men, with three people $(0.6 \%)$ identifying as a non-binary gender. Their level of education is above the German average $(72 \%$ hold a university degree) and they are mostly over 50 years of age: $69 \%$ are above that age. Women are on average about eight years younger than men. Official governmental data in Germany does not collect information about ethnicity or race but the so called 'migration background.' A person with 'migration background' either does not hold the German nationality, was born outside of Germany, or rather one of their parents was born outside of Germany. According to official government data, $25 \%$ of the population living in Germany has this migration background (Destatis, 2020). The vast majority of our respondents has no personal or family background of immigration (85\%), which is less than the German average (cf. Table 1).

We cannot state whether our respondents reflect the sociodemographic of the PEN membership since there is no data collection at PEN available, which would allow us to compare the respondents with the membership. But since, to become member, one needs to have achieved relevant merits in the literary world, it can be assumed that the PEN membership is older, with high levels of education. We assume that our return on female authors is higher than in the PEN membership.

Since most authors work for different outlets, we asked what their different outlets are and what their primary working income is. Almost all of the respondents consider themselves as writers (92\%), the other eight percent see themselves as journalists, translators, or publishers. Asked where the primary income stems 
Table 1. Respondents.

$(n=526)$

\begin{tabular}{|c|c|c|}
\hline \multicolumn{3}{|l|}{ Gender } \\
\hline Women & 260 & $51 \%$ \\
\hline Man & 247 & $48.4 \%$ \\
\hline Non-binary & 3 & $0.6 \%$ \\
\hline All respondents ( $n=16$ chose not to answer) & 510 & $100 \%$ \\
\hline \multicolumn{3}{|l|}{ Age } \\
\hline Under 39 yrs. & 49 & $9.9 \%$ \\
\hline 40 to 49 yrs. & 84 & $17 \%$ \\
\hline 50 to 59 yrs. & 151 & $30.5 \%$ \\
\hline Above 60 yrs. & 211 & $42.6 \%$ \\
\hline All respondents ( $n=31$ chose not to answer) & 495 & $100 \%$ \\
\hline \multicolumn{3}{|l|}{ Migration background } \\
\hline No migration background & 426 & $84.7 \%$ \\
\hline With migration background & 77 & $15.3 \%$ \\
\hline All respondents ( $n=23$ chose not to answer) & 503 & $100 \%$ \\
\hline \multicolumn{3}{|l|}{ Main profession/income } \\
\hline Author/writer/poet, essayist, novelist & 369 & $72 \%$ \\
\hline Journalist & 32 & $6 \%$ \\
\hline Script author & 7 & $1 \%$ \\
\hline Editor & 22 & $4 \%$ \\
\hline Translator & 23 & $5 \%$ \\
\hline Other (lecturer, blogger, publisher...) & 57 & $11 \%$ \\
\hline All respondents ( $n=16$ chose not to answer) & 510 & $100 \%$ \\
\hline
\end{tabular}

Source: Author.

from, three quarters of respondents (72\%) work primarily as poets, essayists, and novelists, which we summarize as writers/authors. Other primary activities are journalism (6\%) and translating (5\%). The others work for publishing companies as editors or script authors.

The respondents write mostly fiction (66\%), such as crime novels (34\%) or children's books (19\%). The literary work of the respondents aims at presenting the aesthetics of language (55\%) and wants to stimulate an emotional reaction in the reader $(50 \%)$. At the same time, they seek to entertain (48\%), formulate critique (42\%), and represent reality (40\%). Furthermore, the respondents strive for artistic expression (38\%).

In relation to the internet and their everyday professional life, they report primarily to use online search engines (93\%), but also social networks, in particular Facebook (64\%).

The open questions with free text fields were answered comprehensively and in detail. This shows that the issue is seen as important for the writers. We have conducted an extra content analysis to summarize these full text answers in detail, since they deliver the qualitative interpretation of our quantitative measurements. The high number of respondents in comparison with the totality of the PEN memberships indicates, as well, that the questions raised were considered as being of outstanding relevance.

\section{Results}

\subsection{Threats to Free Speech and Experiences of Harassment}

The survey began with the assessment of the general situation of free speech and possible threats to it in Germany. More than three quarters $(78 \%)$ of the respondents voiced concern about the current state of free speech in Germany, and a third of these respondents even saw free speech highly endangered (34\%). One of the key questions was the personal experience with attacks, harassment, or hate speech. We asked: "Have you experienced in your professional or private life harassment, insults, or attacks?" In the following, we will use harassment, attacks, and assault as synonyms. Concerning this point, half of the respondents $(52 \% ; n=273$ ) reported having experienced themselves different forms of harassment and attacks. The following presentation of the results will apply to the authors with assault experience or, when noted, compare the authors with such experiences with all respondents. Those who experienced assaults faced them mainly online (69\%; cf. Table 2) or verbally face-to-face (57\%). Only three percent of these assaults were of physical violence. A look at the online attacks shows that Facebook (58\%), the commentary function of online articles (46\%), and personal emails (33\%) 
Table 2. Respondents with attack experiences.

\begin{tabular}{|c|c|c|c|c|c|c|}
\hline & \multicolumn{2}{|c|}{$\begin{array}{c}\text { Personal experience } \\
\text { with attacks }\end{array}$} & \multicolumn{2}{|c|}{$\begin{array}{l}\text { Only those with experience: } \\
\text { attacks via internet }\end{array}$} & \multicolumn{2}{|c|}{$\begin{array}{l}\text { Only those with experience: } \\
\text { verbal attacks face-to-face }\end{array}$} \\
\hline & cases & $(\%)$ & cases & $(\%)$ & cases & $(\%)$ \\
\hline \multicolumn{7}{|l|}{ Gender } \\
\hline Woman & 131 & $51 \%$ & 103 & $75 \%$ & 73 & $53 \%$ \\
\hline Man & 140 & $57 \%$ & 91 & $64 \%$ & 88 & $62 \%$ \\
\hline All & 271 & $54 \%$ & 194 & $69 \%$ & 161 & $57 \%$ \\
\hline \multicolumn{7}{|l|}{ Migration } \\
\hline No migration background & 222 & $52 \%$ & 159 & $69 \%$ & 132 & $58 \%$ \\
\hline With migration background & 45 & $59 \%$ & 34 & $71 \%$ & 26 & $54 \%$ \\
\hline All & 267 & $53 \%$ & 193 & $70 \%$ & 158 & $57 \%$ \\
\hline \multicolumn{7}{|l|}{ Age } \\
\hline Up to 39 yrs. & 32 & $65 \%$ & 30 & $91 \%$ & 15 & $45 \%$ \\
\hline 40 to 49 yrs. & 49 & $58 \%$ & 42 & $82 \%$ & 24 & $47 \%$ \\
\hline 50 to $59 \mathrm{yrs}$. & 75 & $50 \%$ & 59 & $77 \%$ & 42 & $55 \%$ \\
\hline Over 60 yrs. & 105 & $50 \%$ & 59 & $54 \%$ & 71 & $65 \%$ \\
\hline All & 261 & $53 \%$ & 190 & $70 \%$ & 152 & $56 \%$ \\
\hline
\end{tabular}

Source: Author.

are the media through which the online attacks mainly occur. Twitter, although less used by respondents, also plays a role (15\%).

According to Chen et al. (2018), Eckert (2017), and Stahel and Schoen (2019) women and people of colour are more likely to receive online harassment. Our study partly confirms these results. Authors with a migration background experience more attacks than authors without ( $7 \%$ above the average). Differing from other findings, our results show that men experience slightly more attacks, but the kind of attack differs by gender. Men experience them significantly more frequently verbally face-to-face, while women mainly online. Additionally, there is an interesting significant age gap: The younger the authors are the more likely they are to experience attacks, mainly via the cyberspace.

Online harassment is more likely to be targeting younger people and people with a migration background. Women are attacked online, while face-to-face verbal attacks affect more men. Looking at the intersectional correlation of the attacks, we can state that older people, regardless of gender and migration background, experience less attacks. Younger men with a migration background experience the highest degree of harassment. For women, the migration status is less relevant.

Half of the respondents (48\%) reported being aware of incidents of hate speech, threats, or intimidations directed at colleagues. According to the reported perception of the writers, the negative experiences mentioned here are a new phenomenon. Three in four respondents (70\%) hold the impression that incidents of threats, intimidations, and hateful reactions have increased over the last three years.

\subsection{Origins and Reasons for Attacks}

Verbal as well as online harassment mainly comes from anonymous persons (66\%) and from persons who are principally identifiable by name but unknown to the author $(35 \%)$ or the audience in general $(22 \%)$. To get more qualitative information we asked with an open-ended question who the perpetrators are. As mentioned above, the writers made extensive use of the free text fields: 124 out of 273 people who had experienced assaults responded. We conducted a content analysis to summarize the answers in groups. According to these answers, every third attacked author believes that the harassment comes from right-wing political groups. They are a major force in cases of harassment. More than a third (34\%, $n=42$ ) of the open-ended answers centred on these groups. Mainly, this includes persons from the right-wing political spectrum, such as the "Identitarians," "members of the political party AfD and their supporters," "Reichsbürger, Pegida supporters," "Far-right groups," and "Neo-Nazis" (cf. glossary, in Supplementary File). Very few answers mentioned pressure from the political left.

Besides right-wing groups, public authorities and institutions $(n=20)$ are mentioned as well. This includes the "police" and the "judiciary" or, as far as the writers' own literary environment ( $n=18$ ), the "German writers' union" as well as "writer colleagues." Experiences of harassment or intimidations from the economic sphere ("enterprises," "corporations," "real-estate companies," $\mathrm{n}=16$ ) and the media milieu ("media owners," "public broadcasters," "interviewees," $n=14$ ) were also reported, but these did occur rarely.

According to the respondents, the main causes of the various forms of harassment are dissatisfaction with the 
theme of the story and reservations against the assumed political orientation and views of the author. Another reason for assaults is the way the facts are presented (cf. Figure 1). Also relevant, but less mentioned, is prejudice against gender and religion/world view.

Summarizing, a relevant portion of the attacks comes from right-wing political groups voicing their dislike over the themes and contents of the respondent's work.

\subsection{Consequences of the Assaults}

These attacks have effects on the well-being of the assaulted authors and their professional life and work.
Additionally, these assaults also affect authors without personal experience of attacks, since they have heard or have knowledge of attacks against their colleagues and react accordingly. Among those with personal experience, the attacks have primordially an impact on the emotional well-being (63\%); however, more than half of them also feel restricted in their everyday working life (51\%). Physical health, financial livelihood, private life, and freedom of movement are in turn less affected. In general, these impairments also apply to those who have no personal experience of attacks, as they also feel that their well-being and their professional life are affected (40\%; cf. Table 3).

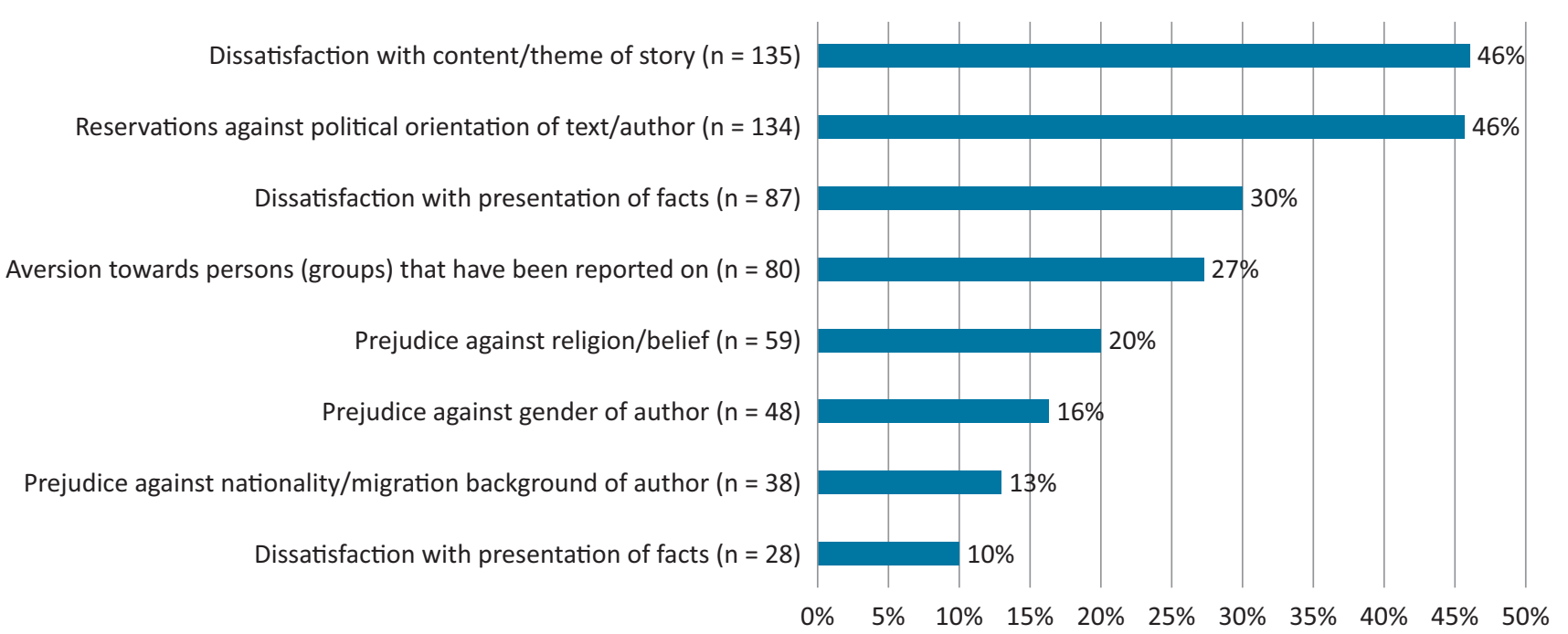

Figure 1. (Assumed) causes for harassment $(n=273$, only respondents with assault experience). Source: Author.

Table 3. Consequences of harassment.

Given answers: yes/no. Multiple answers possible

Respondents with harassment

All respondents

Effect on professional work

experience $(n=273)$

$(n=526)$

I feel encouraged with my work and will not be intimidated

$60 \%$

I evaluate events and issues with greater care

I reduce sensitive and critical stories/themes

I write less on controversial subjects

I play down controversial information

I tailor stories to fit the interests of my clients

I stop writing about sensitive and critical stories

I pass that subject over to a colleague

Effect on social media use

I have reduced or avoided activities in social media

Personal effects

Effects on my psychological well-being

Effects on my daily work

Effects on my personal life

Effects on my financial existence

Effects on my health

Effects on my mobility

Source: Author. 
The attacks also have a direct impact on literary work and everyday working life. One out of four of the authors who have experienced attacks (23\%) has become more cautious in the assessment of facts. One in five (21\%) writes less about sensitive topics, and one in eight (12\%) writes less about controversial subjects.

However, the number of those who have completely given up dealing with a topic due to concerns about attacks $(3 \%)$ or have passed it to a colleague $(2 \%)$ is marginal.

The attacks also show effects on the use of social media. Four out of ten respondents have changed their behaviour in online communication and research. A third of the respondents with negative experiences $(36 \%)$ in- dicate that they have reduced or avoided social media activities in recent years. In this context, no differences can be stated in view of gender or migration background.

This self-restraint contrasts with an opposite trend: Six out of ten authors affected by attacks (60\%) work more encouraged, with greater self-confidence and consider that their work is now more important than ever. This tendency is also evident among those who have had no experience of attacks. Most of them refuse to be stopped or intimidated by threats.

In the commentary sections of the open answers, three quarters of all respondents mention worries or potential changes regarding their professional behaviour (75\%; cf. Table 4). The fears mentioned apply more to lit-

Table 4. Potential threats to the profession (open answers with examples of quotes).

Threats Examples of quotes/translated from German

1. Adapted writing/selflimitation/self-censorship

$(18 \%, n=69)$

2. Loss of quality

$(13 \%, n=50)$

3. Assaults, harassment and stalking/mobbing

$(12 \%, n=48)$

4. Degradation of literary culture/the audience

$(10 \%, n=38)$

5. Threat to free speech

$(5 \%, n=21)$
That artists/writers are discouraged from their work by the threat of harassment or controversies, or as they eschew topics as an act of prophylactic self-censorship; You should not censor yourself;

That an inner censorship kicks in and prohibits you to write what urgently needs to be said, leading in consequence to a distorted public image of an issue.

Increasing loss of quality in general;

Pressure from clients;

Fake news prevails against facts;

Diminished funding for quality journalism.

Infiltration of governmental agencies by far-right radicals, insufficient law enforcement and prosecution of criminal activity, threats and intimidation by intolerant agents;

The anonymity of threats, enabled and supported/protected by "social media";

Threats, verbal abuse by right-wing groups;

The paring down of ethical norms, verbal assault and abuse, intentional misinterpretation, the decline of inhibition threshold to resort to violence and hate;

That I don't want to work in my profession anymore, because the mental strain is becoming too hard.

It is made difficult for writers to build up an audience online;

Bloggers are no longer allowed to post their reviews without marking them as advertisements. The chance to develop an audience is decreased for unestablished authors;

The ultimate demise of the public acknowledgment of literary quality;

That a shrinking number of readers has an interest in complex topics;

The variety of literature is set to decrease even further, because big publishing houses are only pushing mainstream literature. So, if you are working in a niche field, you need to go to the smaller publishing houses, which means in turn that you are not able to reach the broad public.

Threats, abuse by right-wing groups, persons. A general neglect of literature, art. Limitation of freedom of expression and certain topics;

That hate mails etc. pose a threat to free speech, because they aim at silencing people;

A culture of debate is curtailed, the tone becomes more aggressive, knock-out arguments, thwart any discussion.

Source: Author. 
erature and free speech in general and less to individual habit changes. This includes in particular self-limitations in writing like self-censorship or self-restrictions $(n=69)$. As an example: "artists/writers/journalists are discouraged from their work by the threat of harassment or controversies, or as they eschew topics as an act of prophylactic self-censorship."

Many respondents are worried about the potential loss of quality $(n=50)$ : an "increasing loss of quality in general" or due to "pressure from clients."

Equally often, assaults, harassment, and stalking/ mobbing $(n=48)$ are mentioned as elements of danger in view of the "infiltration of governmental agencies by far-right radicals, insufficient law enforcement and prosecution of criminal activity, threats and intimidation by intolerant agents." The degradation of literary culture and the audience ( $n=38$ ) can be identified as the fourth most relevant category. This includes the following statements: "the ultimate demise of the public acknowledgment of the quality of literature" or the observation "that a shrinking number of readers has an interest in complex topics." The threat to free speech $(n=21)$ is perceived clearly by the writers. They are afraid of "threats, abuse by right-wing groups," the "general neglect of literature, [and] art" as well as the constraints on free speech and the debate of controversial issues.

In the second part of the section we asked: "What do you see as a (future) challenge in your profession?" The respondents mention raising awareness and maintenance of a critical attitude ( $n=44)$ : "To raise awareness, to speak out against idiots, against sexism, racism, against social change for the negative. Counter agitation with facts."

A further aspect is "clean" and fact-based writing $(n=35)$ : "The challenge: to inform oneself as comprehensively as possible, in the best case to learn about all the facets of an 'issue' in order to make your own judgement" and to "ensure a fair balance within the discourse." Or: "The challenge is and will be to distinguish truth from untruth and to insist on an open, fair dialogue and to defend it." Taking a stand for your own opinion $(n=30)$ remains crucial. The respondents demand writers to "open your mouth!" and "to have the courage to stand by your own opinion," "not to let hate and adversity refrain oneself from critical subjects. Issues of gender and racism are particularly useful in fantastic literature, but many shy away from the conflict because they are worried about being stigmatized."

\section{Conclusions}

This study looks at the current state of freedom of expression in a time of shitstorms and online harassment, and of personal attacks on literary writers in Germany. The key question is whether the experience of harassment and assault leads to changes in the professional behaviour and, as the last resort, to self-censorship.

The main results can be summarized as follows: According to their own perception, three quarters of all respondents say that incidents of threats, intimidations, and hateful reactions have been on the rise over the last three years. Half of the respondents have experienced harassment in connection with their own texts. The assaults come in particular from the right-wing or farright political spectrum. These reports are in accordance with the findings of most of the research that looked at journalism (cf. Betche \& Hoffmann, 2018; Binns, 2017; Löfgren Nilsson \& Örnebring, 2016).

In our survey, online harassment targeted more younger people and persons with a migration background. Male authors get attacked slightly more often. This result differs from surveys on journalism (Eckert, 2017). Women are attacked mainly online, while faceto-face verbal attacks especially affect men. Looking at the intersectional correlation of the attacks, we can state that older people, regardless of gender and migration background, experience less attacks. Younger men with a migration background experience the highest degree of harassment. Considering women, the migration status does not matter as much. These results sound conclusive in view of the fact that most of the attacks are driven from right-wing groups for whom the migration status of the author seems to matter more than the gender. This outcome again differs from other findings (Eckert, 2017).

The assaults and a general development in society, perceived by the writers as worrying, not only have consequences for their personal wellbeing, but also for their daily work: Even taking into account that half of the respondents maintain that they act with more self-assurance despite the fear of experiencing harassments, a fifth reports an altered, more careful treatment of issues that could spark controversy. Here, our findings confirm the results of most studies on journalism (Obermaier et al., 2018). It is important to highlight that the respondents of our study are primordially literary writers of fictional essays and novels. They are not involved in the daily routine of a journalistic newsroom, do not attend press conferences or demonstrations for professional reasons, and usually work alone. Nonetheless, the experienced attacks and imagined harassment lead to more careful behaviour.

A tendency to self-censorship can be observed in one out of five authors, if a wide definition is used (Clark \& Grech, 2017). These authors are more careful and have changed their working behaviour. Even arguing that this number seems to be low, these missing voices reduce considerably the degree of plurality in society. For most of the respondents, online platforms are not only seen as a potential threat to literary freedom. The personal experiences led to a significantly modified online behaviour. Apart from personal consequences, the withdrawal from the digital public sphere does more than only putting its inclusive function into question. In addition, the risks embedded in online communication and the deliberate obstruction of inclusion through hate speech, shitstorms, and harassment leads to a shift in the perception of social reality. 
Hate speech and shitstorms are used consciously to impede others in their exercise of their freedom of expression. As shown, such attacks on the digital communication of writers do have consequences on their literary work and lead to self-limitation. Besides the fact that free speech is under pressure to a much larger degree in other countries around the world, the findings of this study are no less a call to alarm for a society that values freedom of speech as one of the greatest achievements of its democratic constitution.

If public voices are silenced, this can lead to an erosion of democratic structures. Without a pluralism of opinions and debates on the development of society, there is an increasing danger that the legitimacy of our democracy will be undermined slowly but surely, with the consequence of destructive frameworks taking hold.

If the opportunities of the public to participate in democratic discourses are limited by phenomena like harassment and hate, this will influence opinion-making throughout society. Opinions, perspectives, and knowledge run the risk of becoming marginalized and extraneous to decision-making processes.

Abuse and hatred are suffered by those who go public and seek to debate social issues. For many, threats and hatred are something they have to deal with in their everyday lives. Some even must resort to extensive security measures. The hatred can have serious consequences for the lives of individuals, as it can also lead to passivity in word or deed. Self-censorship, resignation, and conformance in view of assault and hate are an issue that has to be taken seriously in a democratic society. Writers have an important function in the democratic discourse. It is to be ensured that their voices remain audible in spite of the challenge arising from the dilemma of the advocacy of freedom of speech as an essential value of plural societies in view of those who make use of it aiming decidedly at averting inclusion and plurality.

\section{Acknowledgments}

The authors would like to thank the members of PEN Center Germany for their participation and extensive responses.

\section{Conflict of Interests}

The authors declare no conflict of interests.

\section{Supplementary Material}

Supplementary material for this article is available online in the format provided by the author (unedited).

\section{References}

Altmeppen, K.-D., Bieber, C., Filipović, A., Heesen, J., Neuberger, C., Röttger, U., . . . Thomas, T. (2019). Öffentlichkeit, Verantwortung und Gemeinwohl im digitalen Zeitalter: Zur Erforschung ethischer Aspekte des Medien- und Öffentlichkeitswandels [Publicity, responsibility and common welfare in the digital age: On the research of ethical aspects of changes in media and public]. Publizistik, 4(1), 59-77.

Amadeu-Antonio-Stiftung. (2016). "Geh sterben!" Umgang mit Hate Speech und Kommentaren im Internet ["Go and die!" Dealing with hate speech and comments on the Internet]. Berlin: Amadeu-AntonioStiftung. Retrieved from https://www.amadeuantonio-stiftung.de/w/files/pdfs/hatespeech.pdf

Beck, K. (2015). Kommunikationswissenschaft [Communications science]. (4th ed.). Stuttgart and Konstanz: UTB GmbH and UVK Verlag.

Betche, P., \& Hoffmann, M. (2018). Feindbild "Lügenpresse" III: Schulterschluss der Gewaltbereiten [Enemy image "Lying press" III: Closing of ranks between those who are ready to use violence]. Leipzig: European Centre for Press \& Media Freedom. Retrieved from https://www.ecpmf.eu/archive/files/ ffm-germany_2018.pdf

Binns, A. (2017). Fair game? Journalists' experiences of online abuse. Journal of Applied Journalism \& Media Studies, 6(2), 183-206.

Chen, G. M., Pain, P., Chen, V. Y., Mekelburg, M., Springer, N., \& Troger, F. (2018). 'You really have to have a thick skin': A cross-cultural perspective on how online harassment influences female journalists. Journalism, 21(7), 877-895.

Clark, M., \& Grech, A. (2017). Journalists under pressure: Unwarranted interference, fear and self-censorship in Europe. Strasbourg: Council of Europe.

Destatis. (2020). Migration und Integration: Bevölkerung in Privathaushalten nach Migrationshintergrund insgesamt [Migration and integration: Population in private households according to migration background]. Destatis (Federal Office of Statistics). Retrieved from https://www.destatis.de/DE/Themen/GesellschaftUmwelt/Bevoelkerung/Migration-Integration/ Tabellen/migrationshintergrund-geschlechtinsgesamt.html;jsessionid=58D76ED97FC09E0DD 5E3497ECA0EB49A.internet8711

Duggan, M., Rainie, L., Smith, A., Funk, C., Lenhart, A., \& Madden, M. (2014). Online harassment. Washington, DC: Pew Research Center. Retrieved from http://www.pewinternet.org/2014/10/22/onlineharassment

Eckert, S. (2017). Fighting for recognition: Online abuse of women bloggers in Germany, Switzerland, the UK and US. New Media \& Society, 20(4), 1282-1302.

Eckes, C., Fernholz, T., Geschke, D., Klaßen, A., \& Quent, M. (2019). \# Hass im Netz: Der schleichende Angriff auf unsere Demokratie. Eine bundesweite repräsentative Untersuchung [\# Hate on the net: The creeping attack on our democracy-A nationwide representative survey]. Jena: Institut für Demokratie und Zivilgesellschaft. Retrieved from https:// blog.campact.de/wp-content/uploads/2019/07/ 
Hass_im_Netz-Der-schleichende-Angriff.pdf

Freedom House. (2017). Freedom of the press 2017. Retrieved from https://freedomhouse.org/sites/ default/files/FOTP_2017_booklet_FINAL_April28.pdf

Gardiner, B., Mansfield, M., Anderson, I., Holder, J., Louter, D., \& Ulmanu, M. (2016, April 12). The dark side of Guardian comments. The Guardian. Retrieved from https://www.theguardian.com/technology/ 2016/apr/12/the-dark-side-of-guardian-comments

German PEN Center. (n.d.). PEN-Charta [PEN charter]. German PEN Center. Retrieved from https://www. pen-deutschland.de/de/pen-zentrum-deutschland/ die-charta-des-internationalen-pen

Geschke, D., Klaßen, A., Quent, M., \& Richter, C. (2019). Executive summary \# Hass im Netz: Der schleichende Angriff auf unsere Demokratie. Eine bundesweite repräsentative Untersuchung [Executive summary \# Hate on the net: The creeping attack on our democracy-A nationwide representative survey]. Jena: Institut für Demokratie und Zivilgesellschaft (IDZ). Retrieved from https://blog.campact.de/wpcontent/uploads/2019/07/Hass_im_Netz_Executive Summary.pdf

Habermas, J. (1990). Strukturwandel der Öffentlichkeit [The structural transformation of the public sphere]. Frankfurt am Main: Suhrkamp Verlag.

Höhne, V., \& Reimann, A. (2019, September 19). Gericht hält Pöbeleien gegen Künast für zulässig [Court considers taunts against Künast permissible]. SPIEGEL Online. Retrieved from https://www. spiegel.de/politik/deutschland/renate-kuenastberliner-landgericht-haelt-beschimpfungen-fuerzulaessig-a-1287592.html

Krone, J. (2019). Mythos Sichtbarkeit des Publikums [The myth of audience visibility]. In J. Krone (Ed.), Medienwandel kompakt 2017-2019: Schlaglichter der Veränderung in Kommunikation, Medienwirtschaft, Medienpolitik und Medienrecht-Ausgewählte Netzveröffentlichungen [Media change compact 2017-2019: Highlights of changes in communication, media business, media policy and media law-Selected net publications] (pp. 169-174). Wiesbaden: VS Verlag.

Leets, L. (2002). Experiencing hate speech: Perceptions and responses to anti-Semitism and antigay speech. Journal of Social Issues, 58(2), 341-361.

Löfgren Nilsson, M., \& Örnebring, H. (2016). Journalism under threat: Intimidation and harassment of Swedish journalists. Journalism Practice, 10(7), 880-890. https://doi.org/10.1080/17512786.2016. 1164614

Mayer-Uellner, R. (2003). Das Schweigen der Lurker: Politische Partizipation und soziale Kontrolle in OnlineDiskussionsforen [The silence of the lurkers: Political participation and social control in online discussion forums]. Munich: Fischer, Reinhard Verlag.

Meibauer, J. (2013). Hassrede: von der Sprache zur Politik [Hate speech: From language to politics]. In J. Meibauer (Eds.), Hassrede/Hate Speech: Inter- disziplinäre Beiträge zu einer aktuellen Diskussion [Hate speech: Interdisciplinary contributions to a current discussion] (pp. 1-16). Giessen: Justus-LiebigUniversität Gießen.

Nolden, M. (2020). Rassismus im Netz [Racism on the Net]. In H. Friese, G. Rebane, M. Nolden, \& M. Schreiter (Eds.), Handbuch Soziale Praktiken und Digitale Alltagswelten [Manual on social practices and digital daily life] (pp. 351-361). Wiesbaden: VS Verlag.

Obermaier, M., Hofbauer, M., \& Reinemann, C. (2018). Journalists as targets of hate speech: How German journalists perceive the consequences for themselves and how they cope with it. Studies in Communication and Media, 7(4), 499-524.

Papendick, M., Rees, Y. P. M., Wäschle, F., \& Zick, A. (2020). Hass und Angriffe auf Medienschaffende: Eine Studie zur Wahrnehmung von und Erfahrungen mit Angriffen auf Journalist*innen [Hate and attacks on media workers: A study on the perception of and experience with attacks on journalists]. Bielefeld: Institut für interdisziplinäre Konflikt- und Gewaltforschung. Retrieved from https://mediendienstintegration.de/fileadmin/Dateien/Studie_Hass_ und_Angriffe_auf_Medienschaffende.pdf

PEN America. (2015). Global chilling: The impact of mass surveillance on international writers. PEN America. Retrieved from https://pen.org/research-resources/ global-chilling

PEN America. (2017). Online harassment survey: Key findings. PEN America. Retrieved from https://pen. org/online-harassment-survey-key-findings

PEN International. (n.d.). The PEN Charter: PEN International. Retrieved from https://pen-international.org/ who-we-are/the-pen-charter

Preuß, M., Tetzlaff, F., \& Zick, A. (2017). Hass im Arbeitsalltag Medienschaffender: "Publizieren wird zur Mutprobe." Studie zur Wahrnehmung von und Erfahrungen mit Angriffen unter Journalist_innen [Hate in the everyday work of media workers: "Publishing is a test of courage." Study on the perception of and experience with attacks on journalists]. Berlin: Mediendienst Integration.

Prinzing, M. (2015). Shitstorms: Nur Wutstürme oder begründete demokratische Proteste? [Shitstorms: Just storms of anger or justified democratic protest?]. In K. Imhof, R. Blum, H. Bonfadelli, O. Jarren, \& V. Wyss (Eds.), Demokratisierung durch Social Media? [Democratization through social media?] (pp. 153-176). Wiesbaden: VS Verlag.

Reid-Steere, E. (2000). Das Selbst und das Internet: Wandlungen der Illusion von einem Selbst [The self and the Internet: Changes in the illusion of one's self]. In U. Thiedeke (Eds.), Virtuelle Gruppen: Charakteristika und Problemdimensionen [Virtual groups: Characteristics and problem dimensions] (pp. 265-283). Wiesbaden: VS Verlag.

Reporters Without Borders Germany. (2018). Rangliste der Pressefreiheit 2018: Nahaufnahme Deutschland 
[Ranking list of press freedom 2018: Close-up of Germany]. Berlin: Reporters Without Borders Germany. Retrieved from https://www.reporter-ohnegrenzen.de/fileadmin/Redaktion/Downloads/ Ranglisten/Rangliste_2018/Nahaufnahme_ Deutschland_2018_-_Reporter_ohne_Grenzen.pdf Rieger, D., Schmitt, J. B., \& Frischlich, L. (2018). Hate and counter-voices in the Internet: Introduction to the special issue. Studies in Communication and Media, 7(4), 459-472.

Schmitt, J. B. (2017). Online Hate Speech: Definition und Verbreitungsmotivationen aus psychologischer Perspektive [Online hate speech: Definition and motivations for spreading from a psychological perspective]. In K. Kaspar, L. Gräßer, \& A. Riffi (Eds.), Online Hate Speech: Perspektiven auf eine neue Form des Hasses [Online hate speech: Perspectives on a new form of hate] (pp. 51-56). Munich and Düsseldorf: kopaed Verlag.

Schütte, C. (2013). Zur Funktion von Hass-Zuschreibungen in Online-Diskussionen: Argumentationsstrategien auf islamkritischen Websites [On the function of hate attributions in online discussions: Argumentation strategies on Islam-critical websites]. In J. Meibauer (Ed.), Hassrede/Hate Speech: Interdisziplinäre Beiträge zu einer aktuellen Diskussion [Hate speech: Interdisciplinary contributions to a current discussion] (pp. 121-142). Giessen: JustusLiebig-Universität Gießen.

Seethaler, J., Hanitzsch, T., Keel, G., Lauerer, C., Steindl, N., \& Wyss, V. (2019). Zwischen Kontinuität und Wandel: Journalismus in Deutschland, Österreich und der Schweiz [Between continuity and change: Journalism in Germany, Austria and Switzerland]. In T. Hanitzsch, J. Seethaler, V. Wyss (Eds.), Journalismus in Deutschland, Österreich und der Schweiz [Journalism in Germany, Austria and Switzerland] (pp. 237-256). Wiesbaden: VS Verlag.

Sorce, G. (2020). Journalist-activist boundary work in populist times: The \#NazisRaus debate in German media. Journalism Practice. Advance online publication. https://doi.org/10.1080/17512786.2020. 1755885

Sponholz, L. (2018). Hate Speech in den Massenmedien:
Theoretische Grundlagen und empirische Umsetzung [Hate speech in mass media: Theoretical foundations and empirical implementation]. Wiesbaden: VS Verlag.

Springer, N. (2014). Beschmutzte Öffentlichkeit? Warum Menschen die Kommentarfunktion auf OnlineNachrichtenseiten als öffentliche Toilettenwand benutzen, warum Besucher ihre Hinterlassenschaften trotzdem lesen, und wie die Wände im Anschluss aussehen [Stained public sphere? Why people use the commentary features on online news sites as a public restroom wall, why visitors read their legacies nonetheless, and how the walls look like afterwards]. Münster: LIT Verlag.

Stahel, L., \& Schoen, C. (2019). Female journalists under attack? Explaining gender differences in reactions to audiences' attacks. New Media \& Society, 22(10), 1849-1867.

Struth, A. K. (2019). Hassrede und Freiheit der Meinungsäußerung [Hate speech and freedom of expression]. Berlin and Heidelberg: VS Verlag.

Sweeney, M. S. (2015, August 13). How women journalists can protect themselves online. Columbia Journalism Review. Retrieved from http://www.cjr. org/q_and_a/how_women_journalists_can_protect themselves_online.php

Thorpe, V. (2019, December 7). Nobel winner Peter Handke avoids genocide controversy in speech. The Guardian. Retrieved from https://www.theguardian. com/books/2019/dec/07/nobel-winner-handkeavoids-genocide-controversy-in-speech

Weber, P., Prochazka, F., \& Schweiger, W. (2015). Was bewirken die Trolle? Ausstrahlungseffekte von Nutzerkommentaren auf die wahrgenommene journalistische Qualität von Nachrichtenbeiträgen [Which effects do trolls have? Spillover of user comments on the perceived journalistic quality of news articles]. Paper presented at the 60th German Communication Association annual conference, Darmstadt, Germany.

Zeh, J. (2012). Digitale Revolution. Wie wollen wir lesen? [Digital revolution. How do we want to read?]. ZEIT Online. Retrieved from https://www.zeit.de/2012/ 47/Buecher-Internet-Literatur-Verleger/seite-3

\section{About the Authors}

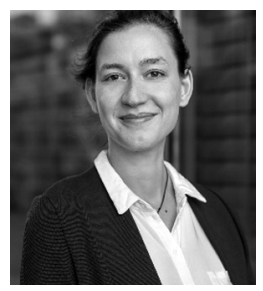

Juliane Wegner (MA) is a PhD Student in political communication and Research Associate of the Institute for Media Research at the University of Rostock, Germany. Her research and teaching interests include (online) communication and media-especially self-presentation on social media platforms. Research activities in particular focus on content, distribution, and impact of hate speech as well as (right-wing) propaganda. 


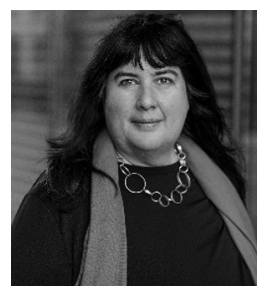

Elizabeth Prommer is Professor and Chair for Communication and Media Studies and Director of the Institute for Media Research at the University of Rostock, Germany. Her research focusses on all media platforms (cinema, TV, internet, mobile media, and future new forms) and the changing audiences and production structures in converging media environments. She has led the project "Mediated Time" funded by the German research foundation (DFG). Several of her studies document the underrepresentation of women in media production and representation.

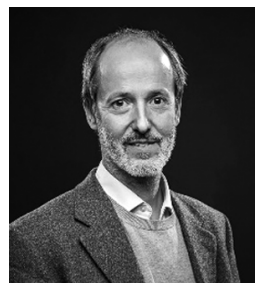

Carlos Collado Seidel is Professor for contemporary history at the University of Marburg, Germany. His main research areas are dictatorial regimes and nationalism in the 20th and 21 st centuries. He has been Secretary General of the German PEN, a writers' association committed to the defence of freedom of expression at a national and international level. His principal fields of involvement are the achievement of gender equality and the defence of plurality against growing nationalist intolerance in Western societies. 